\title{
Educational Cooperation and Exchange Between African Countries and China: Challenges _An Interview with Professor Liu Hongwu
}

\author{
Jean Gonondo \\ Institute of Education Science, Zhejiang Normal University, 688 Yingbin Avenue, Jinhua City, Zhejiang \\ Province, 321004 China
}

\begin{abstract}
This interview with one of the Chinese famous scholars who moved forward the Africa-China relations, provides some understanding on the ongoing educational cooperation and exchange between both sides. In this interview, Prof. Liu Hongwu answers to the interviewer's questions concerning the role that education has to play in the process of mutual understanding and support between African countries and China. It also presents and discusses the interconnections between Chinese Culture, History and Education and the challenges to be faced by both educational systems.
\end{abstract}

Keywords: Africa; China; Educational Cooperation and Exchange

Interviewee: Liu Hongwu (刘鸿武)

Professor, PhD Candidates' Supervisor, Zhejiang Normal University (ZJNU), China.

Professor Liu Hongwu, Director of the Institute of African Studies (The first comprehensive Institute dedicated to African Studies in Chinese Higher Education Institutions) at Zhejiang Normal University, is a Changjiang Scholar appointed by the Ministry of Education (MOE) and a Qianjiang Scholar of Zhejiang Province. He also serves as Vice President of Chinese Asia and African Studies Society, Chinese Research Society of African Affairs and Chinese Society of African Historical Studies. He studied at the University of Lagos in Nigeria and at Dar Es Salaam University in Tanzania. So far, he has been in charge of one key research project sponsored by the National Social Science Fund and another key research project commissioned by MOE Humanities and Social Sciences Fund. He has completed many research projects commissioned by the National Social Science Fund, published hundreds of papers and over 20 monographs. His main research areas are "World History", "International Relations", "China-Africa Relations" etc. He also received several national awards for his numerous achievements in teaching and research works. Professor Liu Hongwu was awarded as one of the winners of the "China-Africa Friendship Awards_- the Ten Chinese who Moved African People" in 2009.

Interviewer: Jean Gonondo

$\mathrm{PhD}$ Candidate, majoring in Higher Education Studies, with China-Africa Higher Education Cooperation and Exchange as research interest, Zhejiang Normal University, China.

Precision: [This interview took place on January $22^{\text {nd }}, 2018$ at Zhejiang Normal University, China.]

Jean Gonondo: Dear Professor Liu, I'm very glad and honoured to meet you today to ask some questions about the existing educational cooperation between African countries and China. You did lots of research on international relations, and especially about the relations between African countries and China. First of all, could you introduce us to the ongoing international relations, in your understanding, how do international community look at Chinese educational system? And how do you see the actual relations between African countries and China?

Liu Hongwu: The relations between China and Africa is not just a matter of material dealings. We certainly need it, for example, a long-term economic cooperation to promote our common development. However, the most important in the relations between China and Africa goes beyond aid, money, and material, it is about mutual respect, mutual understanding and mutual support. Friends in need are the most precious. China and Africa became friends when both were poor. It is worth respecting and also promoting such a true relationship.

In the past, the international community did not understand very well Chinese educational system. There are many misunderstandings, they think that China is an authoritarian society, undemocratic country, etc. In fact, it is not like what they think. The education in China from the ancient time till now is opened and accessible to all civilians, any ordinary person can receive education. And as long as you are good in school, you can take part in 科举 [kējǔ] (Examination System of selecting officials) and become an official. Regardless of you being a worker in a city or a peasant in a rural area, as long as you study hard, you can be a high-level official in the government. How great is this educational system! Is there any more democratic system in the world than this one?

Jean Gonondo: Professor, you have been doing lots of research about "World History", "International Relations", what is your understanding of "Democracy"?

Liu Hongwu: When we talk about a country being democratic or not, it is not necessarily the fact of seeing 
whether it has elections and a multiparty system. Democracy is firstly about whether people have the right or not to enter into the country's political system. In China, as long as you work very hard, you can enter the political system. Secondly, democracy is about whether the State system and bureaucracy is opened or not to the commoners. In China, it is open to anyone. Today, anyone can join the Chinese Communist Party as long as he or she studies and works hard. For example, today our universities' students can join the party; and if they work hard they can work in the government as officials after their graduation. An undemocratic system is where there is a monopoly of power, a "nobility" as the European system. China isn't_—China is a civilian nation. The conception of democracy in our society is intimately linked to our education.

Jean Gonondo: How do you relate democracy to education?

Liu Hongwu: In the history of China, education played a very important role. It selected out China's elites, excellent talents to govern the country. Confucius said: “学而优则仕”[xué ér yōu zé shì], which means “A good scholar can become an official". China's core idea is that if you learn well, you can become an official; excellent people should serve the country. The state officials must be selected amongst the best, the most excellent and talented people. How good system it is!

Now if you look at the Western system, as long as you can go to the polls, protest in the streets, go to parades, then you can be elected. Nowadays, these types of "democratic politics" are many. For example, "Trump has money, thus he can stand to be elected". But in China, it is not like this. In China, if you want to become an official, govern the country, then you must be very well educated, possess rich knowledge. Thus, as long as he or she studied well and work very hard, then he or she (any ordinary person) can become an official. Isn't this a democracy?

Jean Gonondo: How important is education in Chinese culture?

Liu Hongwu: China is a country where education is very developed, and we have a history of thousands of years of education, which started with Confucius. The Chinese civilization is based on education. Why is it that in ancient times we were advanced? - because we attached great importance to education, we have this tradition, this spirit. Confucius is an educator and thinker, he is China's greatest thinker. During all his life, he was talking about benevolence and education. So, to understand China's history, Chinese culture and civilization, we must first understand the Chinese education.

So what is the advantage of this system, putting education in the first place? This system lets and encourages all the Chinese to go to school to study and learn. Then, from them, it selects all the talented people and put them together into the country's political team. That is why now you can see that Chinese officials are the best people in the community. If someone should ask you, do you wish to be governed by the talented, welleducated and best people of the country or by people with poor qualifications, certainly you will choose to be governed by well-educated, talented people of the country. That is why, if you study very well, you obtained a Bachelor, Master or $\mathrm{PhD}$ degree, then you should serve the society, the country. If the whole society is in such an atmosphere, then the country can have enough positive energy, and can grow up very fast.

I think people should not waste their time to go for the election every day and fight one another. We need to concentrate our energy on working together for our society. China has thousands of years in this regard, the civil service system has existed for more than 1000 years. But Westerners do not understand, Africans too do not understand. They always say that China is developing today as a "neo-colonialist", "plundering global resources" and "centralized" country. In fact, we are not. Westerners do not understand China. They think the system is "autocratic", "backward" with a "bad system", but China continues to develop. China is now one of the most stable and fast-growing countries; a country where most of the people are very happy and satisfied. If China really has a lot of problems as some think, why is it that after more than 30 years of development it continues to develop? In fact, they do not understand China.

If you want to explain why China is developing today, it is necessary to understand the role of education in China's economic development. Education has played a driving role in economic development. Contrary to many other countries in the world, we have nurtured the needs of our nation, education has trained needed people in the society.

One of the most important system in China is the educational system which is based on the Confucian culture. So, to understand China, you must first understand the Chinese educational system.

Jean Gonondo: Since 1987 you have been doing researches about the World History, China-Africa Relations. From December 1990 to December 1991 you studied at the University of Lagos in Nigeria, then from January to July 2003, you have been a Senior Visiting Scholar at the University of Dar es Salaam in Tanzania. You also go to Africa regularly, for example, only in 2017, you went to so many African countries like South Africa, Zambia, Egypt, Kenya, Malawi and Tanzania, and you visited their higher education institutions (HEIs). Please, could you tell us, what are your impressions about African countries HEIs in general?

Liu Hongwu: African HEIs students and intellectuals are separated from the folks and commoners, they consider themselves higher than the latter. Most African countries universities' professors studied in Europe and/or in America, they are most of the time dressed in suits. The minds of these professors are full of Western 
theories which are actually out of their realities in the sense that the theories are not related to their society and daily life. They are not like Chinese cadres and intellectuals who need to go to the grassroots, think and worry about their people. The African universities and their intellectuals are detached from the common people. In Africa, there are a huge number of poor people, rural areas lack a lot of basic necessities, but their universities are "enclosed" and "surrounded". University professors are living in villas, driving University cars. They and the ordinary people are two different worlds.

In addition, the teaching contents are taken from the West which almost has nothing to do with their realities. Some knowledge given in the university is incompatible with many of the actual needs of Africa. For example, the theory of political science. African universities are talking and teaching a lot of theories set by the Westerners for themselves. These theories talk about democracy, human rights etc., but they cannot solve the real political problems faced by African countries. Now in many African universities, economic theories are almost the same as Western economic theories, for example, the market economy. In actual fact, the reality of Africa and these theories are two different things. Theory and practice are not linked to one another.

The university and society are disconnected, intellectuals and elites are "divorced" from the ordinary and common people. Have the African political parties, African universities, African intellectuals and the elites really figured out what their country needs? African intellectuals, elites must serve their country's interests, and contribute to the development of their country. They have to do it in a real way, because nowadays, many people only talk, but do nothing.

Jean Gonondo: Recently in December $12^{\text {th }}$, 2017, during your conference given at Tianjin Foreign Studies University, School of Asian and African, you said that "Africa is our Teacher". Did you say it by modesty? In which context do you consider Africa as your Teacher?

Liu Hongwu: This is not modesty, this is an objective fact. I have studied in two African countries, Nigeria and Tanzania. Although, the duration of my studies was not so long, it was very helpful for me. If I had not studied there, I would not have had a real and true idea of Africa.

The Chinese educational system has its own problems. The educational system in many African countries has its outstanding aspects, which are also worth learning for China. For example, I have been to many African universities, I think that the African universities have a particularity. People's pursuit of material life is not as serious as in China today. Now in China, a lot of people are pursuing material life and only look at money. Some of the Chinese university students and professors are doing research, conducting research projects just for the money, they stare at the money and not the pursuit of the spirit. In this regard, I think that some of the professors in Africa are more simple and honest, they do not put money first, and I think this is very good. In addition, in many African universities, the relationship between people is very simple, very natural, and very friendly. Another aspect is that compared to us Chinese, few people are involved in counterfeit. Now in China, we have some businessmen who are cheating other people. In these aspects, China has its own problems.

Another aspect is that Africans are more optimistic, more cheerful, they pay more attention to a happy life. These are also worthy for us. Although some Africans are economically lagging behind us now, their spirit is healthier and happier than some of us. In addition, some African works are worth to be studied by us. For example, African Art, Music, and the studies of African history and culture. Some native works are certainly better than ours. So, if we want to know and understand Africans, we should learn from them. Such as our Institute, we are basing our studies on Africa, so I often tell my colleagues that our best teachers are Africans.

Now in our Institute, we have several teachers from African countries, from Mali, Nigeria, Somalia, I appreciate them. I think they are very good scholars, they have a lot of aspects worth learning by us. They are very diligent, hardworking and they have good personalities. When they go back to their respective countries, they always bring some gifts for us and the Institute; they consider this place as their own home, and I really appreciate them. In our relationship, we need not only to have people with good knowledge, but also with exemplary personality.

Jean Gonondo: Education is one of the very important fields of the cooperation between African countries and China. Please, can you tell us what are the problems existing between both sides in education today? And how can they be solved so that they could play a positive role in the cooperation between African countries and China? Liu Hongwu: In China, we usually say Education should teach people 3 things: it should teach people to be good persons, to learn how to do something, and to acquire knowledge. Nowadays our schools should learn to teach people to behave well, $t$ to learn to do something, help people to acquire valuable knowledge. Confucius said the standards of a good person include: 仁 [rén] Benevolence, 义 [yì] Righteousness, 礼 [lǐ] Courtesy, 智 [zhì] Wisdom, 信 [xìn] Trustworthiness. Today, for example, we should love our country, love our people; the country and the people should be placed in the first place, and individuals as second. When the country needs you, you should serve the country. And Africa also has these traditions. Nowadays, many young Chinese and African people do not know each other, and they do not understand each other. Today, many young people in China do not know much about their education, and I believe Africans are the same. China and Africa have forgotten their own traditions, their own excellent culture. It is difficult to develop based on other peoples' 
culture. Many Africans' old traditions are now unknown to many young people at the universities, they have overlooked a lot of good traditions. So now education needs to restore its own best traditions. Education in Africa must return to Africa's own roots.

Another major problem is that our understanding of each other's educational system is not enough. There are not enough researches about our educational cooperation. Now, Africans do not understand the Chinese educational system, nor do Chinese about the African countries educational system.

The other problem is that the level of cooperation between China and Africa is still relatively low. Now, the main form of educational cooperation between China and African countries is students' exchange. Compared to African students coming to China, Chinese students going to Africa are very few, it is unbalanced. There is not enough exchange among our students. There are more African students coming to China now, perhaps they understand more about the Chinese educational system. However, this form of exchange is more directly linked to the students themselves than the country or the universities. African governments and universities do not know much about the Chinese educational system and may not be too interested in it. For example, in African countries, in universities, and even in research institutions, there are few people studying and doing research about the Chinese educational system. There may not be many books on Chinese educational system written by Africans. Whether it is about the China ancient history, the Chinese educational thought, or the current Chinese educational system, all these are unknown and not understood by many Africans.

Another problem is that a lot of Chinese teachers and students who are doing research about Africa do not want to go to Africa, but always want to travel to Europe and the United States. I encourage my colleagues and students to go to Africa to do their research, because if we do not learn from Africans how will we know and understand Africa?

I think Africa is a very promising land; we should vigorously promote educational cooperation between China and Africa. 